\title{
ANALISIS KESULITAN KEUANGAN PERUSAHAAN PERBANKAN DAN LEMBAGA PEMBIAYAAN
}

\author{
Iskandar Putong; Engelwati Gani \\ Jurusan Akuntansi, Fakultas Ekonomi dan Komunikasi, BINUS University \\ Jln. K.H. Syahdan No. 9, Palmerah, Jakarta Barat 11480
}

\begin{abstract}
Analysis of financial distress at the main company that has sold its shares in an open society (go public) becomes so important because most companies always display the good side of the company in the form of financial reporting data each year. For ordinary people the financial statements audited by a valid and authorized institutions listed on stock exchange by naked eye showed a good performance in finance, but in a more in-depth analysis of the data the form of numbers that will give I different conclusion to the eyes economists and financial analysts to the case. In this study, it is used general sample 4 companies engaged in finance. The Discriminant analysis model using the Altman Z-Score that dissect the financial statements of the company for 3 years showed that not always the companies that have go public must be good financial performance as well. Two of four companies surveyed, in fact, are predicted theoretically bankrupt because the companies were experiencing financial distress.
\end{abstract}

Keywords: financial distress, discriminant altman Z-Score

\begin{abstract}
ABSTRAK
Analisis kesulitan keuangan pada perusahaan utama yang telah menjual sahamnya kepada masrakat umum (go public) menjadi sangat penting karena kebanyakan perusahaan selalu menampilkan sisi baik perusahaan dalam bentuk data laporan keuangan setiap tahun. Bagi orang biasa, laporan keuangan yang diaudit oleh lembaga sah dan resmi yang terdaftar di bursa efek secara kasat mata menunjukkan kinerja keuangan yang baik, tetapi dalam analisis data lebih mendalam berupa angka-angka, saya memberikan simpulan yang berbeda dengan ekonom dan analis keuangan terhadap kasus ini. Pada penelitian ini, digunakan sampel umum 4 perusahaan yang bergerak di bidang keuangan. Model analisis diskriminan yang menggunakan Altman Z-score yang memeriksa laporan keuangan perusahaan selama 3 tahun menunjukkan bahwa perusahaan yang telah go public memiliki kinerja keuangan yang baik. Dua dari empat perusahaan yang diteliti, pada kenyataannya, diperkirakan secara teoretis bangkrut karena perusahaan tersebut sedang mengalami kesulitan keuangan.
\end{abstract}

Kata kunci: kesulitan keuangan, altman Z-score discriminan 


\section{PENDAHULUAN}

Kesulitan keuangan (financial distress) pada perusahaan dapat terjadi karena faktor internal dan eksternal. Secara internal terjadi karena adanya kesalahan profesional yang dilakukan oleh para pengelola perusahaan. Misalkan, kesalahan prediksi, kesalahan kebijakan, dan semacamnya. Kesalahan profesional ini terjadi bukan karena kekurang-mampuan pengelola dari segi pengetahuan dan pendidikan, tetapi karena memang pasar sulit diterka sehingga produksi (barang dan atau jasa) tidak dapat diserap pasar. Sebagai contoh, akibat dari krisis keuangan global yang dimulai di AS menjadikan konsumen di Indonesia berhati-hati pada pengeluaran untuk membelanjakan uang terutama untuk produk yang dibayar dengan cara mencicil. Faktor eksternal terjadi karena kondisi persaingan yang sangat kapitalistis, di mana hanya perusahaan yang memiliki modal dan sumber modal yang sangat besar saja yang sanggup bertahan meskipun hanya mendapatkan margin keuntungan yang relatif kecil. Kondisi ini secara alamiah akan membuat perusahaan kecil dengan struktur dan sumber modal yang terbatas rawan untuk mengalami kesulitan keuangan.

Perusahaan yang menderita kesulitan keuangan memiliki peluang lebih besar untuk mengalami kebangkrutan karena relatif akan mengalami kekurangmampuan untuk meningkatkan pendapatan dan mendapatkan keuntungan (minimal kondisi BEP sulit dicapai atau bahkan tidak tercapai), serta kesulitan membayar pinjaman perbankan dan lembaga pinjaman bukan bank (suku bunga dan coupon).

Perusahaan yang umumnya sangat rawan dengan kondisi faktor internal dan eksternal untuk terjadinya kesulitan keuangan, sebagaimana yang dijelaskan secara singkat di atas, adalah perusahaan yang bergerak di bidang perbankan (banking) dan lembaga pembiayaan (finance). Jenis perusahaan ini umumnya membiayai atau mendanai konsumsi yang bersifat pembayaran tunda (cicilan), di mana performance pembayaran sangat bergantung pada performance konsumen dalam membayar. Dan hal ini sangat bergantung pada kondisi ekonomi yang terjadi.

Dalam penelitian ini, dirasakan sangat bijak untuk menganalisis perusahaan yang bergerak di bidang yang dimaksud, yaitu perusahaan yang bergerak di bidang perbankan (2 perusahaan) dan di bidang pembiayaan (2 perusahaan). Masing-masing perusahaan yang datanya dianalisis adalah perusahaan yang terdaftar (listing) pada Bursa Efek Indonesia (BEI) hingga penelitian ini dilakukan. Rentang tahun data yang dianalisis adalah 3 tahun buku, sejak 2007 hingga 2009 (per Desember), yang telah diaudit dan diumumkan pada situs internet BEI.

Berdasarkan latar belakang yang dipaparkan di atas, maka masalah dalam penelitian ini, yaitu: bagaimanakah kondisi keuangan perusahaan selama 3 tahun terakhir. Apakah mengalami kesulitan keuangan atau tidak. Berdasarkan latar belakang dan rumusan masalah yang dipaparkan di atas, maka masalah dalam penelitian ini dibatasi hanya untuk: menganalisis laporan keuangan perusahaan yang meliputi rasio Working capital/Total assets, rasio Retained earnings/Total assets, rasio Earnings before interest and tax/Total assets, rasio Market capitalization/Book value of debt, dan rasio Sales/Total assets antara rentang tahun 2007 hingga 2009 untuk mengetahui apakah telah terjadi kesulitan keuangan atau tidak pada perusahaan tersebut.

Tujuan dari penelitian ini adalah untuk mengetahui apakah perusahaan yang datanya dianalisis dan objek penelitian antara tahun 2007-2009 ini secara teoretis mengalami kesulitan keuangan atau tidak.

Manfaat penelitian ini, yaitu: (1) bagi peneliti, dapat digunakan untuk menambah pengetahuan dalam bidang analisis laporan keuangan dengan menggunakan analisis diskriminan sehingga tidak hanya memiliki pengetahuan pembukuan semata, dan sebagai tolok ukur dalam penguasaan teori 
akuntansi dan keuangan, serta bagaimana mengaplikasikannya; dan (2) bagi perusahaan, hasil penelitian ini menjadi informasi tambahan untuk mengevaluasi kinerja keuangan, minimal sebagai peringatan dini (early warning) bagi pengelola.

Asumsi dalam penelitian ini merujuk pada data yang tidak mengalami "pengaturan data sesuai keinginan perusahaan" (window dressing), harga relatif tetap dan tidak adanya bailout pada perusahaan yang diteliti. Hipotesis dalam penelitian ini adalah bahwa perusahaan yang masih terdaftar dalam Bursa Efek Indonesia "pasti atau seharusnya" tidak mengalami kesulitan keuangan. Uji hipotesis menggunakan metode deduktif (secara matematis) di mana hasil yang dipercaya adalah exact bukan probabilitas.

\section{Pengertian Kesulitan Keuangan (financial distress)}

Menurut Luciana dalam penelitiannya yang berhubungan dengan kebangkrutan bank, kondisi kesulitan keuangan adalah suatu kondisi di mana perusahaan mengalami delisted sebagai akibat dari laba bersih dan nilai buku perusahaan negatif secara berturut-turut dan perusahaan tersebut telah dimerger (dalam Endri, 2009). Menurut Plat dan Plat (dalam Endri, 2009), kesulitan keuangan (financial distress) adalah tahap penurunan kondisi keuangan yang terjadi sebelum perusahaan dinyatakan bangkrut. Pengertian tersebut menjelaskan bahwa kondisi kesulitan keuangan atau sering disebut sebagai financial distress adalah kondisi di mana perusahaan mengalami keuntungan bersih yang negatif. Dalam artian ini, laporan keuangan perusahaan membukukan rugi dalam nilai buku perusahaan.

Sedangkan kegagalan keuangan adalah terjadinya insolvensi antara dasar arus kas dan dasar nilai saham (Endri, 2009). Bila perusahaan gagal memenuhi kewajiban jatuh temponya, maka inilah disebut insolvensi secara teknis. Ukuran kekayaan bersih perusahaan (asset) bersifat negatif dalam neraca konvensional lebih kecil dari kewajiban.

Berdasarkan pengertian di atas, dapat disimpulkan bahwa kondisi kesulitan keuangan perusahaan dapat diartikan sebagai suatu kondisi di mana perusahaan tidak memiliki kemampuan untuk membayar hutang-hutangnya baik pokok maupun bunganya (tidak mampu memenuhi kewajibannya) sehingga tujuan ekonomi dan bisnis perusahaan tidak bisa tercapai.

\section{Rasio Keuangan dan Rasio Diskriminan Altman}

Secara umum rasio keuangan menurut Brigham dan Gapenski (1996) adalah:

"An analysis of the firm's ratio is generally the first step in a financial analysis. The ratios are designed to show relationships between financial statement account by comparing them. Another purpose of financial ratios analysis is to show the firm's strengths and weakness relatifly with industri averages, and the firm's financial condition" (pp. 622-623).

Dan diterjemahkan bebas sebagai berikut: "Analisis rasio perusahaan umumnya langkah pertama dalam analisis keuangan. Rasio ini dirancang untuk menunjukkan hubungan antara akun laporan keuangan dengan membandingkan mereka. Tujuan lain dari analisis rasio keuangan adalah untuk menunjukkan kekuatan dan kelemahan perusahaan relatif dengan rata-rata industri, dan kondisi keuangan perusahaan."

Menurut Halim (1999), bentuk-bentuk dasar ratio keuangan dapat diklasifikasikan dalam empat golongan, yaitu: (1) rasio likuiditas untuk mengukur kemampuan perusahaan dalam memenuhi kewajiban-kewajibannya dengan segera yang termasuk dalam rasio ini adalah current ratio dan quick ratio; (2) rasio leverage untuk mengukur perbandingan dana yang disediakan oleh pemilik dengan 
dana yang dipinjam perusahaan. Yang termasuk dalam rasio ini adalah: Total Debt to Total asset dan Total Debt to equity ratio; (3) rasio aktivitas yang digunakan untuk mengukur efektif tidaknya perusahaan menggunakan dan mengendalikan sumber daya yang dimiliki perusahaan; (4) rasio profitabilitas yang digunakan untuk mengukur kemampuan perusahaan dalam menghasilkan laba.

Berdasarkan rasio keuangan diatas, Altman (dalam Endri, 2009) menganalisis secara diskriminan rasio keuangan tersebut dengan membuat perbandingan tersendiri atasnya, yaitu: (1) Net Working Capital to Total Asset. Rasio ini menunjukkan kemampuan perusahaan untuk menghasilkan modal kerja bersih dari keseluruhan total aktiva yang dimiliki. Modal kerja bersih didapat dengan cara aktiva lancar dikurangi dengan kewajiban lancar. Rasio ini akan menunjukkan kemampuan perusahaan untuk memenuhi kewajiban-kewajiban lancarnya. (2) Retained Earnings to total Assets. Rasio ini menunjukkan kemampuan perusahaan untuk menghasilkan laba ditahan dari total aktiva perusahaan. Laba ditahan adalah laba yang tidak dibagikan kepada para pemegang saham. (3) EBIT to Total Assets. Rasio ini menunjukkan kemampuan untuk menghasilkan laba dari aktiva perusahaan sebelum dikeluarkan untuk bunga dan pajak. (4) Market Value of Equity to Book Value of Debt. Rasio ini menunjukkan kemampuan perusahaan untuk memenuhi kewajiban dari nilai pasar modal sendiri (saham biasa). Nilai pasar ekuitas sendiri diperoleh dengan cara mengalikan jumlah lembar saham dengan harga pasar saham biasa. Nilai buku hutang didapat dengan cara menjumlahkan kewajiban lancar dengan kewajiban jangka panjang. (5) Sales to Total Assets. Rasio ini menunjukkan apakah perusahaan menghasilkan volume bisnis yang cukup dibandingkan investasi dalam total aktiva.

\section{Model Altman Z-Score}

Altman (1968) adalah salah satu ahli akuntansi keuangan dan statistik keuangan yang melakukan riset berkala tentang bagaimana memprediksi potensi kebangkrutan perusahaan dari berbagai macam jenis usaha. Model Altman ini, menurut Endri (2009), 72\% berhasil memprediksi kebangkrutan dengan benar untuk semua jenis perusahaan, sisanya mendekati dan sama sekali salah (keliru). Ini mungkin disebabkan adanya kontinuitas dan perkembangan dunia usaha dan terlibatnya pemerintah secara langsung untuk membantu perusahaan-perusahaan yang dianggap layak untuk dibantu agar tidak bangkrut.

\section{Kajian Penelitian Sejenis}

Pada 2008, Hawaldi melakukan analisis pada industri kayu yang terdaftar di BEJ periode tahun 2003-2006. Dengan menggunakan model 1, hasilnya menunjukkan bahwa dari 5 perusahaan yang dianalisis semuanya menunjukkan potensi kebangkrutan. Dari 5 perusahaan itu, 2 diantaranya benar-benar bangkrut atau minimal tidak beroperasi hingga akhir tahun periode penelitian ini dilakukan. Berarti, $40 \%$ prediksinya tepat.

Pada 2008 dilakukan penelitian atas 2 perusahaan property besar di Indonesia yang berdomisili di Jakarta. Hasilnya menunjukkan kedua perusahaan itu terancam bangkrut. Akan tetapi, pada kenyataannya perusahaan yang diteliti hingga saat ini masih tegak berdiri kokoh.

Pada 2009, Endri melakukan analisis kebangkrutan atas bank umum syariah dengan menggunakan model yang sama dengan yang digunakan dalam penelitian ini. Dengan menggunakan data 2005-2007, hasil penelitiannya menunjukkan bahwa nilai Z-Score lebih kecil dari 1,81 sehingga Bank Umum Syariah dalam periode itu cenderung mengalami kebangkrutan. Faktanya, selama periode itu bank umum syariah tetap tumbuh dan beroperasi dengan baik, bahkan menuai untung.

Dari ketiga penelitian tersebut, dapat diketahui bahwa model diskriminan Altman ini tidaklah selalu bagus untuk memprediksi kebangkrutan, bukan karena modelnya tidak valid dan reliable, tetapi kemungkinan besar, sebagaimana menurut Putong (2009), peneliti mengabaikan tingkat leverage perusahaan. Seperti dalam penelitian pada perusahaan property di atas, nilai Leverage perusahaan 
bagus. Artinya, keuntungan perusahaan selalu meningkat untuk setiap penambahan produksi dan meningkatkan pendapatan pemilik saham. Menurut Putong (2009), analisis leverage seharusnya dipertimbangkan untuk memprediksi kebangkrutan sebab perusahaan bisa saja memainkan biaya tetap $(F C)$ untuk tetap memperbesar keuntungan minimal dalam laporan keuangan. Dalam konteks ini, penggunaan model Altman untuk mendeteksi kesulitan keuangan perusahaan, tentu saja sangat baik karena analisis rasio yang digunakan oleh model ini sangat valid.

Objek penelitian ini adalah dua perusahaan yang bergerak di bidang perbankan (PT X Tbk. dan PT Y Tbk.), dan dua perusahaan yang bergerak di bidang pembiayaan dan otomotif (PT A Tbk. dan PT B Tbk.). Yang menjadi basis objek utama yang akan diteliti adalah laporan keuangan tahunan yang telah dipublikasikan antara tahun 2007-2009.

Data dalam penelitian ini adalah data kuantitatif dan bersifat sekunder yaitu data laporan keuangan yang telah dipublikasi. Variabel dalam penelitian ini ada 5 yang kesemuanya adalah rasio keuangan yang berhubungan dengan aset perusahaan yaitu:

$$
X 1=\text { Networking capital to Asset }
$$

$\frac{\text { Modal Kerja Bersih }}{\text { Total Aset }}$

$X 2=$ Retained earnig to Total Asset

$\frac{\text { Laba ditahan }}{\text { Total Aset }}$

$X 3=$ EBIT to Asset

$\frac{\text { EBIT }}{\text { Total Aset }}$

X4 = Market value of Equity to book value of debt

$X 5=$ Sales to total aseet

$\frac{\text { Penjualan Total }}{\text { Total Aset }}$

\section{Metode Pengumpulan Data}

Data dikumpulkan dari pemilihan dan pemilahan laporan keuangan yang bersumber dari otoritas sumber data tahunan perusahaan terpilih untuk dianalisis. Laporan keuangan perusahaan yang bersangkutan berbentuk buku dan soft-copy format PDF laporan tahunan. Tidak terdapat kesulitan untuk mendapatkan data karena tersedia dan dapat diunduh tanpa memerlukan izin (tetapi tetap tunduk dengan aturan ilmiah). Semua data yang diperlukan disensus (cut-off). Yang terpenting dari data adalah bahwa tidak ada satu pun data tersebut pernah dianalis untuk tujuan yang sama dengan penelitian ini. 


\section{Alat Analisis yang digunakan}

Penelitian ini menggunakan alat analisis model diskriminan standar Altman Z-Score, yaitu:

Untuk perusahaan keuangan/perbankan:

$Z=0,717 X 1+0,847 X 2+3,107 X 3+0,420 X 4+0,998 X 5$.

Untuk perusahaan non-keuangan secara umum adalah:

$Z=1.2 X_{1}+1.4 X_{2}+3.3 X_{3}+0.6 X_{4}+0.999 X_{5}$

Dengan ketentuan sebagai berikut:

$Z>3,0$, perusahaan tidak mengalami kesulitan keuangan

$Z>1,8$, perusahaan mengalami kesulitan keuangan

$Z$ antara 1,8 dan 3 berada di daerah abu-abu. Artinya, manajemen harus mengelola perusahaan dengan hati-hati karena kesalahan dalam efisiensi akan menyebabkan perusahaan susah mendapatkan keuntungan yang baik pada masa yang akan datang.

\section{PEMBAHASAN}

\section{Profil Objek Penelitian dan Data}

Perusahaan yang datanya menjadi objek penelitian adalah perusahaan yang bergerak di bidang perbankan, lembaga pembiayaan dan otomotif. Adapun perusahaan yang dimaksud adalah: (1) PT "X" Tbk yang begerak di bidang Perbankan; (2) PT "Y" Tbk yang bergerak di bidang Perbankan; (3) PT "A” bergerak di bidang Finance; (4) PT “B” bergerak di bidang Finance.

\section{Analisis Data}

Berdasarkan data yang dilampirkan pada penelitian ini, maka dapat diketahui rata-rata nilai masing-masing variabel adalah sebagai berikut.

Tabel 1 Nilai Rata-Rata Variabel Dan Nilai Z- Score berdasarkan model Altman

\begin{tabular}{ccccc}
\hline \multirow{2}{*}{ Variabel } & \multicolumn{2}{c}{ Perusahaan Perbankan Tbk } & \multicolumn{2}{c}{ Perusahaan Pembiayaan Tbk } \\
\cline { 2 - 5 } & PT “X” & PT “Y” & PT “A” & PT “B” \\
\hline X1 & $-0,0033$ & 0,0148 & 0,1084 & 0,4832 \\
X2 & 0,0176 & $-1,0440$ & 0,3690 & 0,4817 \\
X3 & 0,0883 & 0,0643 & 0,1629 & 0,3827 \\
X4 & 0,0899 & 0,0602 & 0,0816 & 0,2249 \\
X5 & 0,0021 & 0,0426 & 1,1383 & 0,8677 \\
Z-Score & $\mathbf{0 , 3 3}$ & $\mathbf{- 0 , 6 1}$ & $\mathbf{2 , 3 7}$ & $\mathbf{3 , 5 2}$ \\
\hline
\end{tabular}

Sumber: Updating Lampiran

PT “A” nilai $Z<1$,8. Artinya, secara rata-rata perusahaan ini mengalami kesulitan keuangan selama 3 tahun terakhir. Secara teoretis, perusahaan ini dapat diprediksi akan mengalami kebangkrutan pada tahun operasional berikutnya bila kinerja keuangannya tidak segera diperbaiki. Dalam hal perusahaan ini masih tetap bertahan di BEI, mungkin ada pertimbangan lain sebagaimana alasan atas penelitian sebelumnya. 
PT “B” nilai Z < 1,8 (bahkan di bawah 0). Artinya, secara rata-rata perusahaan ini "sangat” mengalami kesulitan keuangan selama 3 tahun terakhir. Secara teoretis, sebenarnya perusahaan ini harusnya dibangkrutkan karena kinerja keuangan perusahaan sangat tidak performable. Bila hingga saat ini perusahaan masih tetap terdaftar pada BEI, besar kemungkinan selain karena faktor penyebab lain, juga mungkin sedang menunggu proses eksekusi “delisting” dari BEI jika seandainya dalam 3 tahun berikutnya (2010 - 2012) tidak mengalami perbaikan yang signifikan.

PT “X” nilai Z antara 1,8 dan 3. Artinya, secara rata-rata kinerja keuangan perusahaan dalam kondisi yang "abu-abu”. Maksudnya, kesalahan pengelolaan pada tahun berikutnya akan membuat perusahaan mengalami kesulitan keuangan. Mengingat nilainya yang mendekati 3 dan jauh di atas 1,8, maka perusahaan ini relatif aman.

PT "Y” adalah perusahaan yang kinerja keuangannya sangat baik. Terlihat dari nilai Z > 3 . Artinya, secara rata-rata kinerja keuangan perusahaan dalam kondisi yang sangat baik dan jauh dari kemungkinan untuk bangkrut secara keuangan. Dari hasil analisis dapat diketahui bahwa dua perusahaan mengalami kesulitan keuangan, satu perusahaan sangat aman, dan lainnya aman.

Tabel 2 memuat penilaian akhir atas kinerja 4 perusahaan di atas.

Tabel 2 Nilai Akhir Model Altman Z-Score

\begin{tabular}{ccccc}
\hline Perusahaan & Nilai Z-Score & Kondisi & Hipotesis Awal & Fakta \\
\hline X & 0,33 & FD & Aman & Tidak aman \\
Y & $-0,61$ & FD & Aman & Tidak aman \\
A & 2,37 & Aman & Aman & Aman \\
B & 3,52 & Sangat Aman & Aman & Aman \\
\hline
\end{tabular}

Sumber: Tabel 1 dan hasil analisis

\section{PENUTUP}

Berdasarkan hasil analisis, dapat diketahui bahwa hipotesis awal atas 2 perusahaan yang bergerak di bidang perbankan secara deduktif ditolak karena fakta secara matematis nilai Z-Score menunjukan hasil yang berlawanan. Sedangkan untuk perusahaan yang bergerak di bidang pembiayaan, hipotesis awal tidak dapat ditolak karena secara deduktif fakta menunjukkan nilai ZScore mendukung hipotesis awal tersebut. Berdasarkan simpulan dapat diketahui bahwa model Altman secara teoretis 50\% benar dan 50\% salah. Hal ini menunjukan bahwa banyak hal sebagaimana yang dipaparkan pada bagian teoretis dan penelitian pendahuluan harus dipertimbangkan untuk mengkaji kinerja perusahaan berdasarkan model analisis Altman Z-Score. Katakanlah model yang digunakan dalam penelitian benar, maka hasil penelitian ini jelas memberikan sinyal kepada calon investor untuk tidak tertarik membeli saham perusahaan perbankan, terutama pada kondisi perekonomian dengan kondisi politik dan keuangan global sangat tidak berpihak pada bisnis ini. Sebagai informasi, antara 2007-2009, adalah tahun di mana terjadi krisis keuangan global yang dipicu oleh bangkrutnya salah satu perusahaan terbesar di bidang keuangan di dunia yaitu Lehman Brothers karena permasalahan kredit kepemilikan rumah yang berisiko tinggi yang berimbas pada dunia perbankan. Dengan menggunakan konsep falsabilitas, maka sebenarnya model Altman ini tidak bisa lagi digunakan secara "tunggal" untuk memprediksi kebangkrutan perusahaan. Karena prinsipnya seberapa banyak pun hasil benarnya, tetapi jika ada satu saja yang salah, maka, model ini salah. Sangat disarankan peneliti selanjutnya menggunakan data perusahaan yang sangat banyak dan menggunakan model berlapis semisal model indeks basis, model spesialisasi, model leverage dan semacamnya untuk memperkuat hasil analisis. 


\section{DAFTAR PUSTAKA}

Brigham, \& Gapenski. (1996). Intermediate financial management. Jakarta: Salemba Empat.

Endri. (2009). Prediksi kebangkrutan bank menghadapi dan mengelola perubahan lingkungan bisnis: Analisis model Altman's Z-Score. Jakarta: ABFI Perbanas.

Halim, \& Sarwoko. (1999). Manajemen keuangan: Dasar-dasar pembelanjaan perusahaan. Yogyakarta: BPFE.

Hawaldi. (2008). Analisis diskriminan Model Altman (Z-Score) dalam mengukur kinerja keuangan untuk memprediksi kebangkrutan pada industri kayu yang terdaftar di BEJ. Jurnal, Jakarta.

Putong, I. (2009). Analisis prediksi kebangkrutan Model Altman Z-Score dengan mempertimbangkan leverage perusahaan. Penelitian Non Publikasi, IMP Consulting, Jakarta. 